\title{
AKTIVITAS ANTIOKSIDAN HIDROLISAT PROTEIN MIOFIBRIL BELUT (Synbranchus bengalensis) YANG DIHIDROLISIS DENGAN ENZIM PAPAIN
}

\section{ANTIOXIDANT ACTIVITY OF EEL MYOFIBRILLAR PROTEIN HYDROLYSATESHYDROLYZED WITH PAPAIN ENZYME}

\author{
Arlina Hidayati*, Joko Santoso, dan Desniar \\ Departemen Teknologi Hasil Perairan, Fakultas Perikanan dan Ilmu Kelautan, Institut Pertanian Bogor \\ Kampus IPB Darmaga, Bogor, Jawa Barat, Indonesia \\ Email: arlinahidayati23@gmail.com
}

Makalah: Diterima 22 Maret 2019; Diperbaiki 19 November 2019; Disetujui 13 Desember 2019

\begin{abstract}
Protein hydrolysates contain bioactive peptides which have several function in order to maintain health and reduce the risk of disease. One of the functions of bioactive peptides is as an antioxidant. This study aims to characterize eel myofibril (Synbranchus bengalensis), determine the effect of papain enzyme ratio and hydrolysis time on eel myofibril protein hydrolysates, determine the antioxidant activity of eel myofibril hydrolysates by using DPPH and reducing power assay, and characterize the hydrolysate of myofibril proteins which have the best antioxidant activity. The results showed that eel myofibril protein contained moisture, fat, protein and ash of 85.91, 0.15, 0.14 and $12.78 \%$ respectively and contained the highest glutamic acid and lysine. Hydrolysates of eel myofibril proteins treated using various enzyme ratio and hydrolysis time had hydrolysates yields ranging from 3.53-9.68\%, the value of hydrolysis degrees $5.20-16.193 \%, I C_{50} 14.24-30.26 \mathrm{mg} / \mathrm{mL}$ for DPPH assay and absorbance 0.125 - 0.190 at a concentration of $5 \mathrm{mg} / \mathrm{mL}$ for reducing power assay. Hydrolysis eel myofibril protein using ratio papain 0.20:100 for 2 hours produced the highest antioxidant activities measuring by DPPH scavenging and reducing power iron. The hydrolysate had molecular weight approximately $19.51 \mathrm{kDa}$. Glutamic acid and lysine became the dominant amino acids of the hydrolysate.
\end{abstract}

Keywords: antioxidant, hydrolysates, myofibril, Synbranchus bengalensis, papain

\section{ABSTRAK}

Hidrolisat protein mengandung peptida bioaktif yang berfungsi untuk menjaga kesehatan dan mengurangi resiko terhadap penyakit. Salah satu fungsi peptida bioaktif adalah sebagai antioksidan. Penelitian ini bertujuan untuk mengkarakterisasi miofibril belut (Synbranchus bengalensis), menentukan pengaruh rasio enzim papain dan lama waktu hidrolisis terhadap hidrolisat protein miofibril belut, menentukan aktivitas antioksidan hidrolisat miofibril belut (uji DPPH dan reducing power), dan mengkarakterisasi hidrolisat protein miofibril yang memiliki aktivitas antioksidan terbaik. Hasil penelitian menunjukkan bahwa miofibril belut memiliki kadar protein, kadar lemak, kadar air dan kadar abu berturut turut yaitu 85,91;0,15;0,14 and 12,78\% serta mengandung asam amino tertinggi yaitu asam glutamat dan lisin. Hidrolisat protein miofibril belut dengan perlakuan perbedaan rasio enzim dan lama hidrolisis memiliki rendemen berkisar antara 3,53-9,68\%, nilai derajat hidrolisis 5,20 - 16,193\%, IC I $_{50} 14,24-30,26 \mathrm{mg} / \mathrm{mL}$ (uji DPPH) dan absorbansi 0,125 - 0,190 pada konsentrasi $5 \mathrm{mg} / \mathrm{mL}$ (uji reducing power). Hidrolisat dengan aktivitas antioksidan tertinggi diperoleh dengan rasio enzim 0,20:100 dan lama hidrolisis 2 jam. Hidrolisat memiliki berat molekul kurang dari 19,51 kDa serta memiliki komposisi asam amino tertinggi yaitu asam glutamat dan lisina.

Kata kunci: antioksidan, hidrolisat, miofibril, Synbranchus bengalensis, papain

\section{PENDAHULUAN}

Belut (Synbranchus bengalensis) merupakan jenis ikan yang hidup dengan iklim subtropis hingga tropis dan tersebar luas di berbagai negara Asia termasuk Indonesia (Khanh dan Ngan, 2010). Belut memiliki kandungan gizi yang diperlukan tubuh yaitu protein, lemak, fosfor, kalsium, zat besi, dan vitamin (Palupi et al., 2014). Protein merupakan salah satu kandungan nutrisi belut yang tergolong tinggi yaitu mencapai $81,25 \%$ (Herawati et al., 2018), sehingga belut dapat berpotensi sebagai bahan baku hidrolisat protein.
Hidrolisat protein merupakan produk yang dihasilkan dari proses pemotongan polipeptida protein menjadi peptida dengan berat molekul rendah (Srikanya et al., 2017). Hidrolisat protein telah dimanfaatkan sebagai sumber nutrisi (Kiewiet et al., 2018), meningkatkan karakteristik produk (Normah dan Noorasma, 2015), dan flavor enhancer (Vijaykrishnaraj et al., 2016). Selain itu, hidrolisat protein mengandung bioaktif peptida yang memiliki aktivitas biologis bagi tubuh sehingga berpotensi sebagai pangan fungsional dan nutrasetikal (Balti et al., 2011). 
Peptida bioaktif merupakan peptida dengan urutan asam amino spesifik (Ovando et al., 2018), terdiri dari 2 - 20 sekuen asam amino dan memiliki fungsi fisiologi bagi tubuh (Chandrasekara dan Shahidi, 2011). Beberapa penelitian menunjukkan peptida bioaktif memiliki fungsi sebagai inhibitor tirosinase (Ochiai et al., 2016), anti-inflamasi (Leo et al., 2016), antioksidan (Mirzaei et al., 2018), antiobesitas (Mudgil et al., 2018), antikanker (Vilcacundo et al., 2018), antihipertensi (Guan et al., 2018), antidiabetes (Harnedy et al., 2018), antimikroba (Farzaneh et al., 2018), dan antitrombotik (Qiao et al., 2018).

Salah satu fungsi penting peptida bioaktif yaitu sebagai antioksidan. Antioksidan merupakan senyawa yang dapat melindungi sel tubuh dari kerusakan akibat radikal bebas (Boligon et al., 2014). Sel tubuh yang mati dapat menyebabkan kerusakan jaringan dan berbagai penyakit kronis seperti arteroklorosis, diabetes, kanker, dan neurodegenaratif (Cheung et al., 2015).

Hidrolisat protein yang mengandung peptida bioaktif antioksidan dapat diproduksi dengan hidrolisis secara kimia maupun enzimatik. Proses hidrolisis secara kimia merupakan hidrolisis dengan asam atau basa, dan memiliki beberapa kelemahan. Suhu tinggi yang digunakan selama hidrolisis dapat merusak beberapa asam amino seperti treonin, sistein, lisin, tirosin dan arginin serta proses netralisasi $\mathrm{pH}$ dapat menghasilkan garam berlebih (Aspevik, 2016). Proses hidrolisis enzimatik menggunakan enzim proteolitik untuk memotong secara spesifik rantai peptida (Ovissipour et al., 2009) sehingga menghasilkan hidrolisat tanpa kehilangan banyak asam amino esensial (Wijayanti et al., 2015) dan memiliki bioaktivitas yang baik terutama aktivitas antioksidan (Klomklao et al., 2013). Aktivitas antioksidan hidrolisat dengan hidrolisis enzimatik dipengaruhi oleh jenis enzim, kondisi hidrolisis dan bahan baku protein yang digunakan. Pemilihan jenis enzim merupakan faktor penting, karena jenis enzim yang berbeda mempunyai perbedaan spesifitas dan menghasilkan karakteristik hidrolisat yang berbeda (Slizyte et al., 2005). Papain merupakan salah satu enzim yang berasal dari tanaman yang telah banyak digunakan untuk memproduksi hidrolisat protein yang memiliki aktivitas antioksidan (Najafian dan Babji, 2015).

Berdasarkan kelarutannya, protein ikan dapat diklasifikasikan menjadi protein miofibril, sarkoplasma, dan stroma. Protein miofibril merupakan komponen utama protein yang mencapai $66-77 \%$ dari total protein dan memiliki karakteristik fungsional yang menguntungkan untuk pangan. Karakteristik fungsional protein miofibril meliputi pembentukan gel (Tahergorabi et al., 2011), solubility, foam capacity, dan emulsion capacity (Cercel et al., 2015). Selain mempunyai sifat fungsional, protein miofibril mempunyai sifat biologis sebagai antioksidan. Beberapa penelitian menunjukkan bahwa hidrolisat miofibril memiliki aktivitas antioksidan yang baik. Ren et al. (2010), telah melakukan penelitian aktivitas antioksidan dari hidrolisat miofibril ikan Karper. Ghassem et al. (2014), telah membuktikan hidrolisat protein miofibril ikan Patin memiliki aktivitas antioksidan yang baik. Najafian dan Babji (2015), telah mengisolasi peptida yang memiliki aktivitas antioksidan dari miofibril ikan Patin. Bahan baku yang berbeda memiliki kandungan kimia yang berbeda (Petrova et al., 2018) sehingga optimasi proses hidrolisis sangat penting untuk menghasilkan hidrolisat yang mengandung peptida bioaktif dengan aktivitas antioksidan yang tinggi (Centenaro et al., 2011). Optimasi diperlukan untuk mengendalikan kondisi hidrolisis meliputi lama hidrolisis, suhu, rasio enzim dan pH (Roslan et al., 2014). Oleh karena itu, perlu dilakukan penelitian tentang potensi hidrolisat protein miofibril belut rawa (Synbranchus bengalensis) sebagai antioksidan yang dihidrolisis menggunakan enzim papain dengan rasio enzim papain dan lama hidrolisis sebagai faktor kajian.Penelitian ini bertujuan untukmendapatkan data karakterisasi protein miofibril belutrawa (Synbranchus bengalensis), pengaruh rasio enzim papain dan lama hidrolisis terhadap hidrolisat protein miofibril belut (Synbranchus bengalensis), memperoleh data aktivitas antioksidan hidrolisat miofibril belut rawa (Synbranchus bengalensis), dan karakterisasi hidrolisat protein myofibril yang memiliki aktivitas antioksidan tertinggi.

\section{BAHAN DAN METODE}

Bahan yang digunakan dalam penelitian ini adalah belut rawa (Synbranchus bengalensis), $\mathrm{NaCl}$, dan enzim papain.

\section{Preparasi Protein Miofibril Belut (Wang et al., 2013b)}

Preparasi miofibril belut berdasarkan penelitian Wang et al. (2013) dengan modifikasi. Protein miofibril belut dipreparasi melalui tiga kali proses pencucian. Pencucian pertama dan kedua dilakukan dengan penambahan daging belut lumat dengan akuades perbandingan 1:3 dan dihomogenisasi selama 5 menit. Homogenat disentrifugasi dengan kecepatan 5000xg suhu $4^{\circ} \mathrm{C}$ selama 20 menit. Supernatan dipisahkan dan pelet didehidrasi dengan menggunakan kain blacu. Pencucian ketiga, pelet disuspensikan dengan akuades 1:3 dan ditambahkan $\mathrm{NaCl} 0,3 \%$, kemudian dihomogenisasi dan difiltrasi dengan menggunakan saringan dengan mesh $1 \mathrm{~mm}$ untuk memisahkan jaringan ikat. Kemudian filtrat disentrifugasi. Pelet didehidrasi dengan pengepresan dengan menggunakan kain blacu. Pelet yang telah didehidrasi merupakan konsentrat protein miofibril. 
Analisis Kandungan Kimia Bahan (AOAC 2005)

Analisis kimia bahan baku belut rawa (Ophisternon bengalense) berdasarkan analisis proksimat AOAC (2005) meliputi kadar air, kadar abu, kadar protein, dan kadar lemak.

\section{Hidrolisis Protein Miofibril Belut (Wang et al. 2013b)}

Hidrolisis protein miofibril belut rawa (Synbranchus bengalensis) berdasarkan metode Wang et al. (2013). Hidrolisis dilakukandengan penambahan enzim papain pada rasio enzim dan protein miofibril $0,1: 100 ; 0,15: 100 ; 0,20: 100$ ke dalam protein miofibril belut dengan pelarut bufer fosfat $(1: 30,02 \mathrm{M})$ pada suhu $50^{\circ} \mathrm{C}$ dan $\mathrm{pH} \mathrm{7,0}$ dengan lama hidrolisis 2, 4 jam dan 6 jam. Setelah waktu hidrolisis tercapai, dilakukan inaktivasi protease pada suhu $85^{\circ} \mathrm{C}$ selama 15 menit dan disentrifugasi pada kecepatan 4800x g, suhu $4{ }^{\circ} \mathrm{C}$ selama 30 menit. Supernatan kemudian dikeringkan dengan freeze drier.

\section{Penentuan derajat hidrolisis (Adler-Nissen1986)}

Derajat hidrolisis ditentukan berdasarkan metode Adler-Nissen 1986 dengan pengendapan Trichloroacetic acid (TCA) 20\% untuk menghasilkan $10 \%$ fraksi protein terlarut dan $10 \%$ fraksi tidak larut.Sebanyak $20 \mathrm{~mL}$ sampel ditambah dengan 20 mL TCA $20 \%$ kemudian diinkubasi pada selama 30 menit dan suhu $37^{\circ} \mathrm{C}$. Selanjutnya campuran disentrifugasi dengan kecepatan 7800xg selama 15menit. Supernatan sampel dianalisis dengan metode Kjeldahl.

\section{DPPH Radical Scavenging Activity (Wu et al., 2003)}

Analisis aktivitas antioksidan menggunakan radikal DPPH berdasarkan Wu et al. (2003). Larutan sampel 1,5 mL ditambahkan 1,5 mL 0,15 mM DPPH dalam etanol $95 \%$. Kemudian diinkubasi pada ruang gelap suhu $37^{\circ} \mathrm{C}$ selama 30 menit dan absorbansi diukur pada $\lambda 517 \mathrm{~nm}$. Absorbansi kontrol diukur dengan cara yang sama dengan sampel namun sampel diganti dengan aquades.

Sampel yang digunakan dilarutkan dengan berbagai konsentrasi yang berbeda untuk mendapatkan nilai $\mathrm{IC}_{50}$ yang menyatakan besarnya konsentrasi larutan sampel yang dibutuhkan untuk mereduksi radikal bebas DPPH sebesar $50 \%$. Persamaan regresi linear $(y=a+b x)$ yang diperoleh dari nilai inhibisi pada setiap konsentrasi digunakan untuk mencari nilai $\mathrm{IC}_{50}$.

\section{Reducing Power (Oyaizu 1988)}

Analisis aktivitas antioksidan menggunakan metode reducing power berdasarkan Oyaizu et al. (1998). Sampel $1 \mathrm{~mL}(5 \mathrm{mg} / \mathrm{mL})$ ditambahkan $2 \mathrm{~mL}$ buffer phospat $0.2 \mathrm{M}\left(\mathrm{pH}\right.$ 6.6) dan $\mathrm{K}_{3}\left[\mathrm{Fe}(\mathrm{CN})_{6}\right]$ kemudian diinkubasi selama 20 menit suhu $50^{\circ} \mathrm{C}$. Setelah inkubasi, sampel ditambahkan $1 \mathrm{~mL}$ TCA $10 \%$ dan disentrifugasi dengan kecepatan 3500xg selama 10 menit. Supernatan $1 \mathrm{~mL}$ ditambahkan 1 $\mathrm{mL}$ aquades dan $200 \mathrm{uL} \mathrm{FeCl}_{3}$. Absorbansi diukur pada $\lambda 700 \mathrm{~nm}$ setelah inkubasi pada suhu $37{ }^{\circ} \mathrm{C}$ selama 30 menit.

\section{Analisis berat molekul dengan SDS PAGE (Laemmli, 1970)}

Analisis berat molekul berdasarkan metode Laemmli (1970). Sampel dilarutkan dalam 5\% SDS dan diinkubasi pada suhu $85^{\circ} \mathrm{C}$ selama 1 jam. Campuran disentrifugasi pada $8500 x g$ selama 5 menit pada suhu kamar. Supernatan yang diperoleh dicampur dengan bufer (Tris $\mathrm{HCl} 60 \mathrm{mM}, \mathrm{pH} \mathrm{6,8}$, mengandung $2 \%$ SDS dan $25 \%$ gliserol) dengan rasio $1: 10(\mathrm{v} / \mathrm{v})$ dan mengandung $10 \% \quad \beta$ merkaptoetanol ( $\beta$-ME). Campuran dipanaskan dalam air mendidih selama 2 menit. Sebanyak $15 \mu \mathrm{L}$ sampel dimasukkan ke dalam gel polyacrylamide yang terdiri dari 8\% running gel dan $4 \%$ stacking gel dan dielektroforesis pada arus konstan $50 \mathrm{~mA} / \mathrm{gel}$ selama 2 jam. Setelah elektroforesis selesai, gel diwarnai dengan $0,05 \%$ (b/v) coomassie biru R-250 dalam $15 \%(\mathrm{v} / \mathrm{v})$ metanol dan $5 \%(\mathrm{v} / \mathrm{v})$ asam asetat selama 1 jam, kemudian destained sampel dengan campuran $30 \%(\mathrm{v} / \mathrm{v})$ metanol dan $10 \%(\mathrm{v} / \mathrm{v})$ asam asetat selama 1 jam. Destained dilakukan kembali selama 30 menit. Berat molekul protein sampel diperkirakan berdasarkan berat molekul marker (Bio-Rad).

\section{Analisis Profil Asam Amino (AOAC 1995) \\ Analisis profil asam amino berdasarkan} AOAC (1995). Karakterisasi jenis asam amino dilakukan untuk mengetahui jenis asam amino yang terdapat pada sampel. Instrumentasi yang digunakan yaitu UPLC (Ultra Performance Liquid Chromatography) Waters 1525 dengan kolom Waters Bondapak NH2 3,9 mm x $300 \mathrm{~mm}$ dan fasa gerak yaitu asetonitril : air (60:40). Standar asam amino yang digunakan pada analisis ini terdiri dari 18 jenis asam amino (histidina, isoleusina, leusina, lisina, metionina, fenilalanina, threonina, triptofana, valina, glisina, alanina, arginina, asam aspartat, asam glutamat, prolina, serina, tirosina, dan sisteina). Sejumlah $100 \mathrm{mg}$ sampel ditimbang dan dimasukkan ke dalam tabung ulir dan ditambahkan $5 \mathrm{~mL} \mathrm{HCl} 6$ N. Hidrolisis selama 22 jam pada suhu $110^{\circ} \mathrm{C}$. lalu diangkat, disaring dengan filter $45 \mu \mathrm{m}$, dan diencerkan dengan akuades dalam labu takar $50 \mathrm{ml}$. Filtrat $500 \mu \mathrm{L}$ ditambahkan $40 \mu \mathrm{m}$ AABA dan 460 $\mu 1$. Sampel sebanyak $10 \mu \mathrm{L}$ ditambahkan $70 \mu \mathrm{L}$ AccQ-Fluor Borate Buffer dan $20 \mu \mathrm{L}$ AccQ Fluor, vortex, biarkan 1 menit pada suhu kamar, lalu diinkubasi pada suhu $55^{\circ} \mathrm{C}$ selama 10 menit. Kemudian $1 \mu \mathrm{L}$ dimasukkan dalam instrumen UPLC.

\section{Rancangan Percobaan}

Rancangan percobaan yang digunakan pada penelitian ini yaitu Rancangan Acak Lengkap Faktorial. Perlakuan yang digunakan yaitu rasio 
enzim dan protein miofibril belut rawa $(0,1: 100$; $0,15: 100 ; 0,20: 100)$ dan lama hidrolisis (2 jam, 4 jam dan 6 jam). Data hasil penelitian yang diperoleh akan dianalisis dengan analisis ragam (ANOVA) dan jika terdapat beda nyata antara taraf perlakuan maka dilanjutkan dengan uji Beda Nyata Jujur (Tukey) pada taraf kepercayaan $95 \%$.

\section{HASIL DAN PEMBAHASAN}

\section{Komposisi Miofibril Belut}

Komposisi kimia daging dan miofibril belut (Synbranchus bengalensis) yang diperoleh dengan perlakuan pencucian sebanyak 3 kali dengan penambahan $\mathrm{NaCl} 0,3 \%$ pada pencucian ketigatersaji pada Tabel 1.

Tabel 1. Komposisi kimia daging dan miofibril belut

\begin{tabular}{lll}
\hline \multicolumn{1}{c}{ Parameter } & Daging $\mathbf{( \% )}$ & Miofibril (\%) \\
\hline Kadar air & $80,26 \pm 0,03$ & $85,91 \pm 0,01$ \\
Kadar abu & $0,91 \pm 0,01$ & $0,14 \pm 0,01$ \\
Kadar lemak & $2,21 \pm 0,03$ & $0,15 \pm 0,01$ \\
Kadar protein & $16,08 \pm 0,00$ & $12,78 \pm 0,02$ \\
\hline
\end{tabular}

Tabel 1 menunjukkan komposisi kimia daging belut dan miofibril belut rawa. Hasil analisis komposisi kimia menunjukkan bahwa daging belut yang digunakan pada penelitian ini memiliki komposisi kimia lebih tinggi dibandingkan dengan belut sawah (Monopterus albus) pada penelitian Astiana et al. (2015), yaitu kadar air 78,90\%, kadar abu $0,33 \%$, kadar lemak $0,12 \%$, dan kadar protein $15.90 \%$. Perbedaan komposisi kimia dapat dipengaruhi oleh spesies, habitat, ukuran tubuh kondisi lingkungan, masa pemijahan (PachecoAguilar et al., 2000), umur dan jenis pakan (Yathavamoorthi et al., 2010).

Miofibril belut diperoleh dengan perlakuan pencucian sebanyak 3 kali dengan penambahan $\mathrm{NaCl} 0,3 \%$ pada pencucian ketiga.Selama proses pencucian, lemak pada daging lumat akan terpisah dari daging dan terapung pada permukaan air sehingga miofibril belut memiliki kadar lemak lebih rendah dibandingkan dengan daging. Hal tersebut serupa dengan penelitian Das et al. (2015), konsentrat miofibril mackerel setelah perlakuan pencucian memiliki lebih rendah dibandingkan dengan bahan bakunya. Kadar lemak yang rendah pada miofibril memiliki nilai positif terhadap hidrolisat protein yang dihasilkan. Menurut Yarnpakdee et al. (2012), fishy smell pada hidrolisat protein ikan dapat disebabkan oleh proses oksidasi lemak yang menyebabkan hidrolisat tidak stabil apabila digunakan sebagai suplemen dan bahan fortifikasi. You et al. (2009) menambahkan bahwa oksidasi lemak dapat menyebabkan warna gelap pada hidrolisat protein.

Kadar air miofibril belut lebih tinggi dibandingkan dengan kadar air daging belut. Hal tersebut dapat disebabkan oleh proses hidrasi protein miofibril selama proses preparasi miofibril. Hal tersebut serupa dengan hasil penelitian Lertwittayanon et al. (2013) dan Das et al. (2015), proses pencucian daging lumat dapat meningkatkan kadar air miofibril ikan barakuda dan ikan mackerel. Menurut Bentis et al. (2005), proses pencucian daging lumat dapat meningkatkan hidrasi daging lumat sehingga menyebabkan proses dehidrasi menjadi lebih sulit.

Kadar abu miofibril lebih rendah dibandingkan dengan daging. Kadar abu pada daging merupakan unsur mineral yang terdapat pada daging. Unsur mineral dalam bentuk garam anorganik yang terdapat dalam sarkoplasma, darah dan plasma akan terlarut dalam air selama proses pencucian daging lumat. Menurut Hassan et al. (2017) proses pencucian dapat menurunkan kadar abu pada konsentrat miofibril yang dihasilkan karena komponen garam anorganik akan terbuang selama proses pencucian.

Kadar protein miofibril belut lebih rendah dibandingkan dengan kadar protein pada daging. Selama proses preparasi miofibril, terjadi pemisahan antara protein miofibril dengan protein stroma dan protein sarkoplasma Hal tersebut tidak berbeda dengan penelitian Shekarabi et al. (2014), kadar protein mengalami penurunan akibat perlakuan pencucian pada proses preparasi miofibril. Menurut Das et al. (2015), persentase kadar protein yang menurun dapat disebabkan menghilangnya protein sarkoplasma dan stroma selama proses pencucian. Ismail et al. (2010) menambahkan bahwa kadar air yang meningkat akan menurunkan kadar protein dalam konsentrat miofibril yang dihasilkan.

\section{Derajat Hidrolisis}

Derajat hidrolisis (DH) merupakan presentase jumlah peptida yang terpotong selama proses hidrolisis (Boutagef et al., 2010). Derajat hidrolisis berpengaruh terhadap berat molekul dan komposisi asam amino yang akan mempengaruhi aktivitas antioksidan peptida yang dihasilkan. Derajat hidrolisis dari hidrolisat miofibril belut tersaji pada Gambar 1.

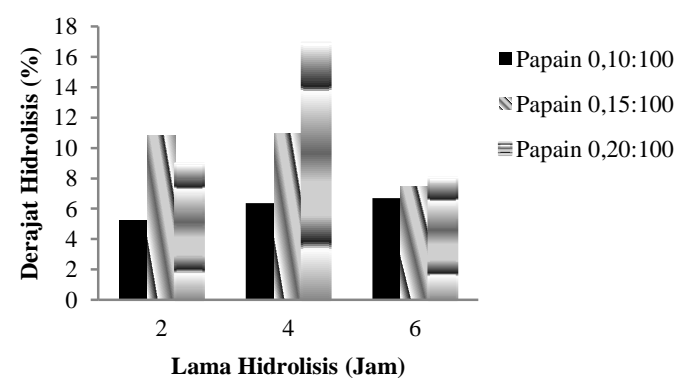

Gambar 1. Pengaruh perbedaan rasio papain dan lama hidrolisis terhadap derajat hidrolisis hidrolisat protein miofibril belut rawa 
Perbedaan rasio enzim, lama hidrolisis dan interaksinya memberikan pengaruh yang berbeda pada persentase jumlah pemotongan peptida $(p<0,05)$. Selama proses hidrolisis, enzim papain akan memecah senyawa protein miofibril belut menjadi senyawa peptida dengan berat molekul yang lebih rendah. Menurut Najafian dan Babji (2015), papain mampu memotong lebih banyak peptida pada miofibril ikan patin sehingga menghasilkan konsentrasi peptida yang lebih tinggi dibandingkan dengan enzim alkalase dan flavourenzyme.

Derajat hidrolisis perlakuan rasio papain dan protein miofibril belut rawa 0,2:100 dengan lama hidrolisis 4 jam merupakan kondisi terbaik untuk menghasilkan persentase jumlah peptida terpotong yang tinggi yaitu $16,93 \%$. Nilai derajat hidrolisis padalama hidrolisis 6 jam lebih rendah dibandingkan lama hidrolisis 4 jam. Hal tersebut menunjukkan tahap hidrolisis dari proses hidrolisis protein miofibril belut. Pada tahap pertama nilai $\mathrm{DH}$ terus meningkat yaitu pada perlakuan lama hidrolisis 2 dan 4 jam sedangkan setelah 4 jam hidrolisis terjadi fase stabil. Perlakuan lama hidrolisis 6 jam tidak menghasilkan DH yang stabil dan terjadi penurunan nilai DH dapat disebabkan peptida hidrolisat sensitif terhadap suhu dibandingkan peptida yang dihasilkan pada perlakuan lama hidrolisis 2 dan 4 jam. Suhu tinggi yang digunakan pada tahap inaktivasi enzim dapat menyebakan koagulasi dan presipitasi peptida sehingga menurunkan jumlah peptida dalam hidrolisat. Miofibril mengandung myosin heavy chain. Menurut Thorarinsdottir et al. (2002), myosin heavy chain mudah terdanaturasi dan tidak stabil. Hal tersebut dapat menjadi faktor yang menyebabkan peptida yang dihasilkan dari protein miofibril belut rentan terhadap suhu tinggi sehingga diperlukan metode alternatif inaktivasi enzim yang tidak mempengaruhi stabilitas peptida hidrolisat.

\section{Rendemen Hidrolisat}

Rendemen hidrolisat menunjukkan persentase hidrolisat protein yang dihasilkan terhadap berat miofibril belut sebelum hidrolisis. Rendemen hidrolisat miofibril belut dapat dilihat pada Gambar 2.

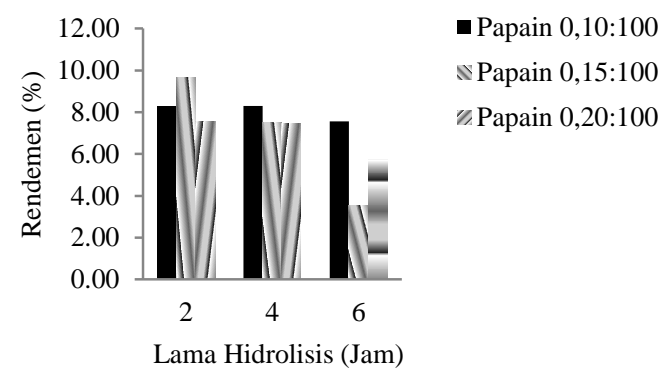

Gambar 2. Pengaruh perbedaan rasio papain dan lama hidrolisis terhadap rendemen hidrolisat miofibril belut
Perbedaan rasio papain dan lama hidrolisis yang berbeda serta interaksi keduanya memberikan pengaruh yang nyata $(p<0,05)$ terhadap rendemen hidrolisat yang dihasilkan. Hidrolisat miofibril belut merupakan jumlah protein terlarut yang dihasilkan selama proses hidrolisis. Perlakuan rasio papain 0,15:100 dengan lama hidrolisis 2 jam menghasilkan rendemen hidrolisat tertinggi namun menurn pada lama hidrolisis 4 dan 6 jam. Penurunan rendemen hidrolisat dapat disebabkan oleh sensivitas peptida pada suhu tinggi. Proses inaktivasi enzim yang dilakukan pada suhu $85^{\circ} \mathrm{C}$ dapat menyebabkan agergasi peptida. Inaktivasi enzim dengan pemanasan dapat merubah struktur peptida yang menurunkan petida bebas dan meningkatkan pembentukan agregat sehingga menurunkan jumlah peptida pada supernatan hidrolisat. Berdasarkan penelitian Foegeding et al. (2002), peptida dari protein whey memiliki sensitifitas tinggi terhadap suhu tinggi dan terjadi agregasi pada suhu $>65{ }^{\circ} \mathrm{C}$. Menurut Wijayanti et al. (2014), agregasi pada peptida disebabkan agregasi disulfida dan interaksi non kovalen. Creusot et al. (2006) menambahkan bahwa agregasi peptide-peptida dapat terbentuk karena interaksi non kovalen pada perlakuan pemanasan suhu $75^{\circ} \mathrm{C}$ dan $85^{\circ} \mathrm{C}$.

Perlakuan rasio papain $0,15: 100$ dengan lama hidrolisis 2 jam menghasilkan rendemen hidrolisat tertinggi dibandingkan dengan perlakuan lainnya yaitu $9,68 \%$. Rendemen hidrolisat miofibril belut lebih tinggi dibandingkan dengan hidrolisat dari daging merah tuna yaitu 1,21 g (Parvathy et al., 2018) namun lebih rendah dibandingkan dengan hidrolisat sarden mencapai 7,01 g (Jeevitha et al., 2014). Menurut Awuor et al. (2017), perbedaan rendemen hidrolisat dapat dipengaruhi oleh tipe enzim dan substrat, kondisi hidrolisis $(\mathrm{pH}$, suhu, lama hidrolisis, rasio substrat/enzim), dan rasio pelarut.

\section{Aktivitas Antioksidan}

Radikal DPPH (2,2-diphenyl-1picrylhydrazyl) merupakan radikal bebas stabil dengan delokalisasi elektron pada molekulnya (Pisoschi et al., 2009). Apabila DPPH bereaksi pada senyawa donor hidrogen, molekul DPPH akan berubah yang dapat diketahui dari perubahan warna ungu yang memudar hingga berwarna kuning (Thaipong et al., 2006). Aktivitas antioksidan hidrolisat miofibril belut yang dianalisis dengan metode DPPH tersaji pada Gambar 3

Perlakuan perbedaan rasio papain, lama hidrolisis dan interaksinya memberikan pengaruh yang nyata $(p<0,05)$ pada kemampuan hidrolisat miofibril belut menangkap radikal DPPH yang direpresentasikan dengan nilai $\mathrm{IC}_{50}$. Nilai $\mathrm{IC}_{50}$ menunjukkan kemampuan senyawa menghambat proses oksidasi sebesar $50 \%$. Nilai $\mathrm{IC}_{50}$ yang rendah menunjukkan aktivitas antioksidan yang tinggi. Proses hidrolisis protein oleh enzim papain akan 
memotong polipetida menjadi senyawa yang lebih sederhana. Semakin banyak peptida yang terbentuk akan meningkatkan interaksi radikal DPPH dengan asam amino peptida sehingga menghasilkan senyawa DPPH yang stabil.

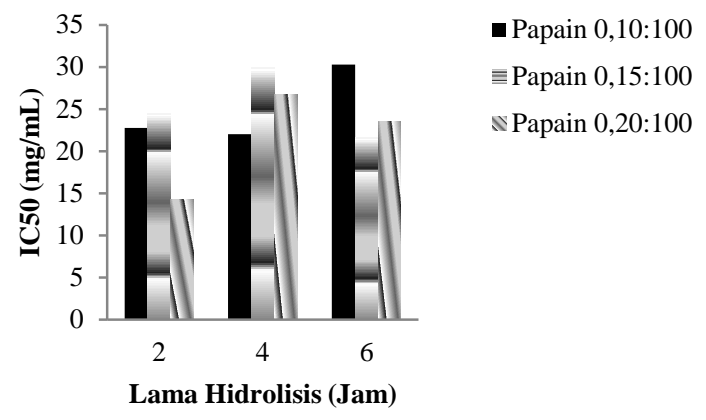

Gambar 3. Pengaruh perbedaan rasio papain dan lama hidrolisis terhadap aktivitas antioksidan hidrolisat miofibril belut dengan pengujian menggunakan DPPH yang ditunjukkan dengan nilai $\mathrm{IC}_{50}$

Nilai $\mathrm{IC}_{50}$ padarasio papain $0,20: 100$ dengan lama hidrolisis 2 jam memiliki nilai $\mathrm{IC}_{50}$ terendah yaitu $14,24 \mathrm{mg} / \mathrm{mL}$ yang menunjukkan aktivitas antioksidan tertinggi. Perlakuan rasio papain 0,20:100 dan lama hidrolisis 2 jam menghasilkan peptida yang memiliki kemampuan mendonorkan hidrogen pada radikal DPPH lebih efektif dibandingkan dengan perlakuan lainnya. Aktivitas antioksidan dari hidrolisat miofibril belut lebih rendah dibandingkan dengan hidrolisat miofibril patin yang dihidrolisis dengan papain, alkalase dan flavouzyme (Najafian dan Babji, 2015) berturut-turut menghasilkan $\mathrm{IC}_{50} 1,12 \mathrm{mg} / \mathrm{mL}, 2,95$ $\mathrm{mg} / \mathrm{mL}$ dan $1,94 \mathrm{mg} / \mathrm{mL}$. Perbedaan aktivitas antioksidan dapat dipengaruhi oleh berat molekul, jenis asam amino pada rantai samping peptida, dan komposisi asam amino peptida (Najafian dan Babji, 2015).

Perlakuan dengan nilai $\mathrm{IC}_{50}$ terbaik tidak memiliki nilai DH yang tinggi. Menurut Raghavan et al. (2008), hidrolisat dengan derajat hidrolisis yang tinggi memiliki aktivitas antioksidan yang tinggi. Menurut Thianisakul et al. (2007), nilai DH hidrolisat ikan round scad (Decapterus maruadsi) yang semakin tinggi memiliki aktivitas antioksidan semakin tinggi. Berbeda dengan hidrolisat miofibril belut, derajat hidrolisis tertinggi yaitu perlakuan konsentrasi enzim 0,2\% dengan lama hidrolisis 4 jam tidak memiliki aktivitas antioksidan yang tinggi. Menurut Moreno et al. (2014), nilai inhibisi DPPH lebih tinggi pada lama hidrolisis yang lebih singkat dapat disebabkan peptida yang memiliki aktivitas antioksidan sudah terbentuk pada awal hidrolisis namun peptida dapat menjadi tidak aktif pada lama hidrolisis yang lebih panjang. Selain itu, menurut Najafian dan Babji (2015) aktivitas inhibisi DPPH dapat dipengaruhi oleh berat molekul jenis asam amino pada rantai samping peptida, komposisi asam amino.

Keberadaan antioksidan pada sampel menyebabkan reduksi ferricyanide komplek $\mathrm{Fe}^{3+}$ menjadi bentuk $\mathrm{Fe}^{2+}$ dengan terbentuknya warna biru Perl's Prussian pada panjang gelombang $700 \mathrm{~nm}$. Absorbansi yang tinggi menunjukkan aktivitas reducing power yang tinggi (Centenaro et al., 2011). Nilai reducing power hidrolisat protein miofibril belut tersaji pada Gambar 4.

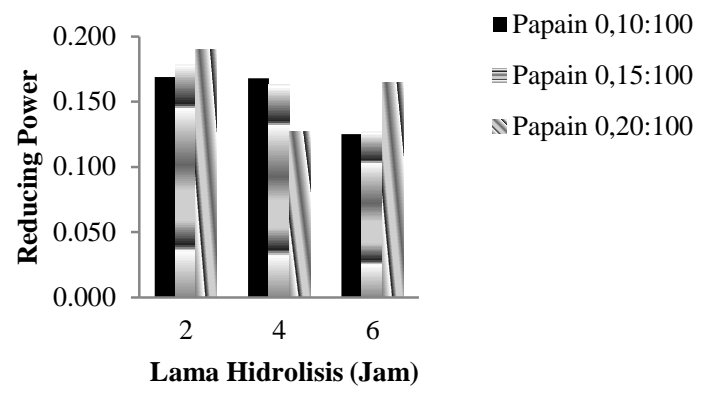

Gambar 4. Pengaruh perbedaan rasio papain dan lama hidrolisis terhadap aktivitas antioksidan hidrolisat miofibril belut dengan pengujian menggunakan reducing power yang ditunjukkan dengan nilai absorbansi pada $\lambda 700 \mathrm{~nm}$

Perbedaan rasio papain dan lama hidrolisis yang berbeda serta interaksi keduanya memberikan pengaruh yang nyata $(p<0,05)$ pada kemampuan hidrolisat miofibril belut mereduksi $\mathrm{Fe}^{3+}$ pada konsentrasi hidrolisat $5 \mathrm{mg} / \mathrm{mL}$. Sampel dengan nilai reducing power yang tinggi menunjukkan kemampuan hidrolisat mendonorkan elektron pada elemen non radikal bebas seperti logam transisi sehingga mencegah terbentuknya radikal bebas. Menurut (Shahidi dan Zhong, 2015), kemampuan antioksidan sebagai donator elektron tidak hanya bereaksi terhadap radikal bebas tetapi mereduksi elemen dengan elektron valensi tinggi. Potensial redoks atau reducing power dari antioksidan merupakan indikator penting aktivitas antioksidan. Jomova dan Valko (2011) menambahkan bahwa logam transisi aktif seperti $\mathrm{Fe}, \mathrm{Cu}, \mathrm{Cr}$, dan $\mathrm{Co}$ mengalami reaksi siklus redoks dan menghasilkan radikal reaktif pada sistem tubuh.

Absorbansi pada perlakuan rasio papain 0,20:100 dengan lama hidrolisis 2 jam berbeda nyata dengan perlakuan lainnya dan memiliki nilai absorbansi tertinggi. Perlakuan rasio papain 0,20:100dan lama hidrolisis 2 jam menghasilkan peptida yang memiliki kemampuan mendonorkan elektron lebih baik dibandingkan dengan perlakuan lainnya. Apabila dibandingkan dengan hidrolisat miofibril patin yang dihidrolisis menggunakan papain (Najafian dan Babji, 2015), absorbansi dari hidrolisat miofibril belut lebih rendah yaitu 0,190 pada konsentrasi $5 \mathrm{mg} / \mathrm{mL}$ dibandingkan dengan hidrolisat miofibril patin yang mencapai 0,305 pada konsentrasi $3 \mathrm{mg} / \mathrm{mL}$. Perbedaan nilai reducing 
power dapat disebabkan oleh panjang peptida, sekuen peptida (Thiansilakul et al., 2007) dan jenis asam amino yang terdapat pada hidrolisat seperti asam amino hidrofobik, asam amino yang bersifat asam dan asam amino yang mengandung gugus sulfur yang memiliki kemampuan sebagai agen pereduksi (Udenigwe dan Aluko, 2011).

\section{Karakteristik Hidrolisat Miofibril Belut}

Hidrolisat dengan aktivitas antioksidan terbaik yaitu hidrolisat yang diperoleh dari perlakuan rasio enzim 0,20:100 dan lama hidrolisis 2 jam dilakukan analisis lebih lanjut meliputi profil berat molekul dan komposisi asam amino. Berat molekul merupakan salah satu faktor yang mempengaruhi aktivitas antioksidan. Sampel dengan aktivitas antioksidan terbaik dianalisis profil berat molekul dengan menggunakan elektroforesis SDS PAGE. Profil berat molekul hidrolisat miofibril belut dapat dilihat pada Gambar 5.

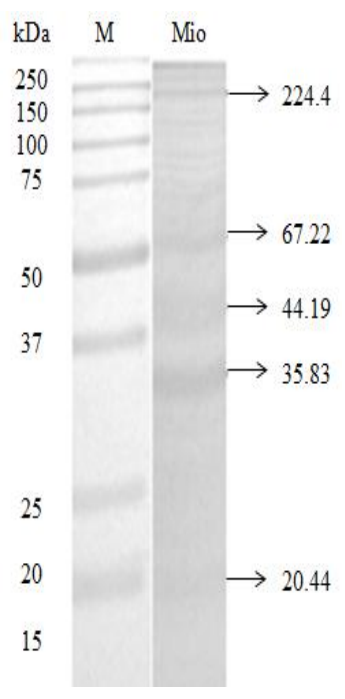

(a)

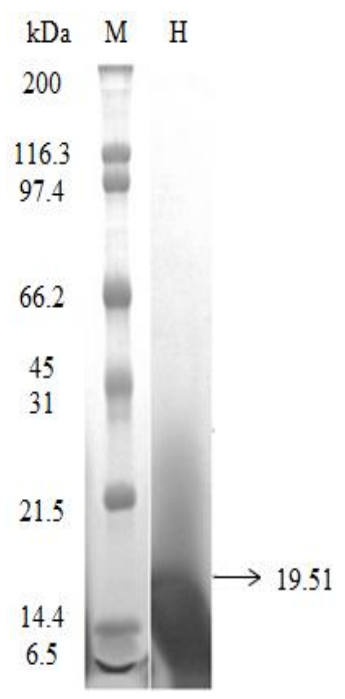

(b)
Gambar 5. Profil berat molekul miofibril belut (a) dan Hidrolisat miofibril belut dengan perlakuan rasio papain 0,20:100 dengan lama hidrolisis 2 jam (b). Miofibril (Mio), hidrolisat miofibril belut $(\mathrm{H})$, marker $(\mathrm{M})$

Gambar 5 menunjukkan protein miofibril belut memiliki berat molekul yang tinggi. Berat molekul miofibril belut yang teridentifikasi yaitu 224,42 kDa, 67,22 kDa, 44,19 kDa 35,83 dan 20,44 $\mathrm{kDa}$ yang diduga merupakan komponen protein miofibril yaitu miosin, aktin dan tropomiosin. Kristinsson dan Rasco (2000), miosin merupakan komponen terbesar pada miofibril mencapai $60 \%$, dan memiliki berat molekul besar yang terdiri dari myosin heavy chains $(223 \mathrm{kDa})$ dan myosin light chains (22 dan $18 \mathrm{kDa}$ ). Menurut Karaulova dan Yakush (2017), berat molekul ikan myosin light chain memiliki berat molekul $16-27 \mathrm{kDa}$, tropomyosin 33 - $36 \mathrm{kDa}$ dan aktin $47 \mathrm{kDa}$. Hidrolisis miofibril dengan rasio papain 0,20:100 dengan lama hidrolisis 2 jam menyebabkan protein terhidrolisis menjadi peptida yang memiliki berat molekul rendah. Berat molekul hidrolisat miofibril belut rawa yang diperoleh dari perlakuan terbaik telah teridentifikasi dengan berat molekul 19,51 kDa dengan konsentrasi tinggi yang ditandai dengan pita tebal pada hasil elektoforesis SDS PAGE. Menurut Bhaskar dan Mahendrakar (2008), berat molekul rendah menunjukkan hidrolisat ikan memiliki nilai nutrisi yang tinggi dan berpotensi sebagai produk pangan fungsional.

Peptida dengan berat molekul rendah berpotensi memiliki aktivitas antioksidan yang tinggi. Hidrolisat miofibril belut memiliki peptida dengan berat molekul yang masih tergolong tinggi sehingga belum memiliki kemampuan berinteraksi dengan radikal bebas yang tinggi. Berat molekul rendah pada hidrolisat kolagen sisik ikan croceine croaker (Psedosciaena crocea) sangat berperan pada aktivitas antioksidan pada radikal DPPH dan reducing power (Wang et al., 2013b). Semakin rendah berat molekul peptida semakin efektif menghambat reaksi radikal bebas. Berat molekul peptida $<3 \mathrm{kDa}$ dari hidrolisat miofibril patin memiliki aktivitas antioksidan yang lebih tinggi dibandingkan dengan peptida dengan berat molekul $10 \mathrm{kDa}$ (Najafian et al., 2013). Berat molekul <3 $\mathrm{kDa}$ memiliki peran penting pada aktivitas antioksidan miofibril ikan grass carp. Peptida yang memiliki 2 - 10 asam amino memiliki aktivitas antioksidan yang sangat baik (Wang et al., 2013a). Hidrolisat dengan berat molekul yang rendah dapat dengan mudah melewati membran usus sehingga mempercepat efek biologis (Ranathunga et al., 2006), dan lebih mudah dan efektif berinteraksi dengan radikal bebas sehingga dapat menghambat siklus propagasi pada peroksidasi lemak (Wang et al., 2013).

Komposisi asam amino hidrolisat protein sangat berpengaruh terhadap aktivitas antioksidan (Najafian et al., 2013). Komposisi asam amino hidrolisat miofibril belut dengan aktivitas antioksidan terbaik tersaji pada Tabel 2

Hidrolisat miofibril belut dengan aktivitas antioksidan terbaik memiliki komposisi asam amino tertinggi pada asam amino hidrofobik. Komposisi asam amino yang bersifat hidrofobik yang tinggi pada hidrolisat miofibril belut tidak berbeda dengan hidrolisat miofibril patin (Najafian dan Babji 2015). Asam amino hidrofobik pada hidrolisat dapat berpengaruh terhadap aktivitas antioksidan. Sekuen peptida yang mengandung asam amino hidrofobik memiliki aktivitas antioksidan yang tinggi (Wattanasiritham et al., 2016). Asam amino hidrofobik memfasilitasi interaksi dengan target hidrofobik, seperti membran sel, dan dengan demikian meningkatkan bioavailabilitas (Himaya et al., 2012). 
Tabel 2. Komposisi asam amino hidrolisat miofibril belut $(\mathrm{g} / 100 \mathrm{~g})$

\begin{tabular}{|c|c|c|c|}
\hline Asam amino & Miofibril Belut & $\begin{array}{l}\text { Hidrolisat Miofibril } \\
\text { Belut* }\end{array}$ & $\begin{array}{c}\text { Kebutuhan Asam } \\
\text { amino (berat badan } \\
70 \mathrm{~kg} \text { ) } * *\end{array}$ \\
\hline $\operatorname{Lisin}^{d}$ & 11,39 & $\mathbf{8 , 5 3}$ & 2,10 \\
\hline Valin $^{\mathrm{a}}$ & 4,37 & 4,12 & 1,82 \\
\hline Isoleusin $^{\mathrm{a}}$ & 4,46 & 3,84 & 1,40 \\
\hline Leusin $^{\mathrm{a}}$ & 7,91 & 7,28 & 2,73 \\
\hline Triptofan $^{\mathrm{c}}$ & 0,68 & 0,59 & 0,28 \\
\hline Histidin $^{\mathrm{d}}$ & 1,83 & 2,44 & 0,70 \\
\hline Metionin $^{\mathrm{a}}$ & 3,08 & 2,62 & 1,05 \\
\hline Threonin ${ }^{\mathrm{e}}$ & 4,89 & 4,77 & 1,05 \\
\hline Fenilalanin ${ }^{c}$ & 3,88 & 4,39 & 1,75 \\
\hline Glisin $^{\mathrm{a}}$ & 3,27 & 4,37 & \\
\hline Alanin $^{\mathrm{a}}$ & 5,15 & 4,70 & \\
\hline $\operatorname{Arginin}^{\mathrm{d}}$ & 5,83 & 7,45 & \\
\hline Asam aspartat ${ }^{\mathrm{b}}$ & 8,37 & 7,11 & \\
\hline Asam glutamat ${ }^{b}$ & 15,37 & 13,53 & \\
\hline Prolin $^{\mathrm{a}}$ & 2,55 & 3,19 & \\
\hline Serin $^{\mathrm{e}}$ & 3,85 & 3,94 & \\
\hline Sistein ${ }^{\mathrm{e}}$ & 0,37 & 0,31 & \\
\hline Tirosin ${ }^{c}$ & 3,45 & 3,94 & \\
\hline AA hidrofobik ${ }^{\mathrm{a}}$ & 30,79 & 30,14 & \\
\hline AA muatan negatif ${ }^{b}$ & 23,74 & 20,64 & \\
\hline AA $\operatorname{aromatik}^{\mathrm{c}}$ & 8,01 & 8,93 & \\
\hline AA muatan positif ${ }^{\mathrm{d}}$ & 19,05 & 18,42 & \\
\hline AA hidrofilik ${ }^{\mathrm{e}}$ & 9,11 & 9,02 & \\
\hline
\end{tabular}

Keterangan: *Hidrolisat miofibril dengan rasio papain 0.20:100 dengan lama hidrolisis 2 jam

***FAO (2013), kebutuhan asam amino untuk dewasa per hari dengan berat badan $70 \mathrm{~kg}$. Kebutuhan asam amino akan lebih rendah pada berat badan kurang dari $70 \mathrm{~kg}$ dan lebih tinggi pada ibu hamil dan anak-anak.

Selain itu, peptida hidrofobik dapat melindungi oksidasi pada makromolekul dengan menyumbangkan proton/elektron ke radikal reaktif (Chi et al., 2015). Hidrolisat miofibril belut memiliki kandungan asam amino dominan yaitu asam glutamat $(13,53 \%)$ dan lisin $(8,53 \%)$. Menurut Yazdi et al. (2012), residu asam glutamat (E) pada peptida memiliki pengaruh penting pada aktivitas antioksidan. Menurut Feng et al. (2018), asam glutamat berpengaruh terhadap aktivitas antioksidan dengan cara memproduksi asam glutamat yang teroksidasi pada proses penghilangan atau reduksi hidrogen peroksida. Hidrogen peroksida merupakan senyawa penting dalam proses pembentukan radikal bebas.Aktivitas antioksidan tidak hanya dipengaruhi oleh jenis asam amino dan komposisi asam amino tetapi dapat dipengaruhi oleh posisi asam amino pada sekuen peptida, struktur sekunder peptida, asam amino pada $\mathrm{N}$-terminal dan C-terminal (Zou et al. 2016), stabilitas peptida terhadap panas (Hou et al. 2014) dan pencernaan (Borawska et al. 2015) serta efek sinergisme antar peptida (Song et al. 2015).

Hidrolisat protein miofibril belut mengandung asam amino esensial yang dapat mencukupi kebutuhan asam amino untuk orang dewasa. Asam amino lisin merupakan asam amino esensial dominan pada hidrolisat miofibril belut.
Kandungan asam glutamat yang tinggi pada hidrolisat dapat memberikan rasa umami sehingga dapat digunakan sebagai flavour enhancer. Oleh karena itu, hidrolisat miofibril belut selain berfungsi sebagai sumber antioksidan, hidrolisat miofibril belut dapat memenuhi kebutuhan asam amino esensial dan sebagai alternatif flavour enhancer pada pangan.

\section{KESIMPULAN DAN SARAN}

\section{Kesimpulan}

Miofibril belut memiliki kandungan protein, lemak dan abu yang lebih rendah dibandingkan dengan daging belut, sedangkan kandungan air terjadi sebaliknya. Miofibril belut memiliki kandungan asam glutamat dan lisin tertinggi. Perlakuan perbedaan rasio enzim papain dan lama hidrolisis berpengaruh nyata terhadap derajat hidrolisis, rendemen hidrolisat dan aktivitas antioksidan. Perlakuan rasiopapain dan miofibril belut 0.20:100 dengan lama hidrolisis 4 jam memiliki aktivitas antioksidan terbaik(metode DPPH dan reducing power). Karakteristik hidrolisat dengan aktivitas antioksidan terbaik memiliki berat molekul kurang dari 19,51 kDa serta memiliki komposisi asam amino tertinggi yaitu asam glutamat dan lisin. 
Saran

Proses purifikasi hidrolisat protein perlu dilakukan untuk mendapatkan aktivitas antioksidan yang lebih tinggi dan mengetahui sekuen peptida yang berperan sebagai antioksidan. Perlu dilakukan pengujian aktivitas antioksidan hidrolisat belut yang dihidrolisis dengan menggunakan enzim yang berbeda.

\section{DAFTAR PUSTAKA}

Adler-Nissen J. 1986. Enzymic hydrolysis of food proteins. London: Elsevier Applied Science Publisher.

[AOAC] Association of Official Analytical Chemist. 1995. Official Methods of Analysis. Washington (USA): The Association of Official Analytical Chemist Inc.

[AOAC] Association of Official Analytical Chemist. 2005. Official Methods ofAnalysis (18 Edn). Mayland (USA): Association of Official Analytical Chemist Inc.

Aspevik T. 2016. Fish protein hydrolysate based on atlantic salmon by-products [disertasi]. Bergen (NO): University of Bergen.

Astiana I,Nurjanah, Suwandi R, Suryani AA, Hidayat T. 2015. Pengaruh penggorengan belut sawah (Monopterus albus) terhadap komposisi asam amino, asam lemak, kolesterol dan mineral.Depik. 4(1): 49-57. Doi: $10.13170 /$ depik.1.1.2366.

Awuor OL, Kirwa ME, Jackim MF, Betty M. 2017. Optimization of alcalase hydrolysis conditions for production of dagaa (Rastrineobola Argentea) protein hydrolysate with antioxidative properties. Ind Chem. 3(1): 1-6. Doi: 10.4172/24699764.1000122.

Balti R, Bougatef A, Hadj A.. 2011. Comparativestudy on biochemical properties and antioxidative activity ofcuttlefish (Sepia officinalis) Protein hydrolysates produced byalcalase and Bacillus licheniformis NH1 proteases. JAmino Acids: 1-9. Doi: 10.4061/2011/107179.

Bentis CA, Zotos A, Petridis D. 2005. Production of fish-protein products (surimi) from small pelagic fish (Sardinops pilchardusts) underutilized by the industry. J Food Eng. 68:303-308.

Doi: 10.1016/j.jfoodeng.2004.06.003.

Bhaskar N, Mahendrakar NS. 2008. Protein hydrolysate from visceral wastes proteins of catla (Catla catla): optimization of hydrolysis conditions for comercial neutral protease. Bioresour Technol. 99(10): 41054111. Doi: 10.1016/j.biortech.2007.09.006.

Boligon AA, Machado MM, Athayde ML. 2014. Technical evaluation of antioxidant
activity.Med chem. 4(7): 517-522. Doi: 10.4172/2161-0444.1000188.

Borawska J, Darewicz M, Pliszkaa M, Vegarud GE. 2015. Antioxidant properties of salmon (Salmo salarL.) protein fraction hydrolysates revealedfollowing their ex vivo digestion and in vitrohydrolysis. $J$ Sci Food Agric. 96: 2764-2772. Doi: 10.1002/jsfa.7441

Boutagef A, Arroume NN, Manni L, Ravallec R, Barkia A, Guillochon D, Nasri, M. 2010. Purification and Identification of novel antioxidant peptides from enzymatic hydrolysates hydrolysates of Sardinella (Sardinella aurita) by-product protein. Food Chem. 118(3): 559-565. Doi: 10.1016/j.foodchem.2009.05.021.

Centenaro GS, Salas-Mellado M, Pires C, Batista I, Nunes M L, Prentice C. 2011. Antioxidant activity of protein hydrolysates of fish and chicken bones. Adv J Food Sci and Technol. 3(4): 280-288. Doi: DJ2012066739.

Cercel F, Stroiu M, Alexe P, Ianitchi D. 2015. Characterization of myofibrillar chicken breast proteins for obtain protein films and biodegradable coatings generation. Agriculture Agricultural Sci Proced. 6 (1): $197 \quad-\quad 205.2$ Doi: 10.1016/j.aaspro.2015.08.059

Chandrasekara A, Shahidi F. 2011. Inhibitory activities of soluble and bound millet seed phenolics on free radicals and reactive oxygen species. J. Agric. Food Chem. 59: 428-436. Doi: 10.1021/jf103896z.

Cheung RC, Ng Tzi B, Wong JH. 2015. Marine peptides: bioactivities and applications. Mar. Drugs. 13(7): 4006-4043. Doi: 10.3390/md13074006.

Chi CF, Hu FY, Wang B, Li ZR, Luo HY. 2015. Influence of aminoacid compositions and peptide profiles on antioxidant capacities of two protein hydrolysates from skipjack tuna (Katsuwonus pelamis) dark muscle. Mar. Drugs. 13: 2580-2601. Doi: 10.3390/md13052580.

Creusot N, Gruppen H, Van Konningsveld GA, de Kruif CG, Voragen AGJ. 2006. Peptidepeptide and protein-peptide interactions in mixtures of whey protein isolate and whey protein isolate hydrolysates. Int DairyJ. 16: 840-849.

Doi: 10.1016/j.idairyj.2005.06.010.

Das N, Khuntia BK, Raychaudhuri U, Dora KC, Ganguly S. 2015. Effect of water washing on the functional properties of fish meat. IJMMTD. 1(1): 8-12. Doi: 10.18231.

[FAO] Food and Agricultural Organization. 2013. Dietary Protein Quality Evaluation in Human Nutrition. Report Of An Fao Expert 
Consultation. Roma (IT): Food and Agricultural Organization of the United Nations.

Farzaneh P, Khanahamadi M, Ehsani M. R, Sharifan A. 2018. Bioactive properties of Agaricus bisporus and Terfezia claveryi proteins hydrolyzed by gastrointestinal proteases. LWT-Food Sci and Technol. 91: 322-329. Doi: 10.1016/j.1wt.2018.01.044.

Feng YX, Ruan GR, Jin F, Xu J, Wang FJ. 2018. Purification, identification, and synthesis of five novel antioxidant peptides from Chinese chestnut (Castanea mollissima Blume) protein hydrolysates. LWT- Food Sci and Technol. 92: 40-46. Doi: 10.1016/j.1wt.2018.01.006.

Foegeding EA, Davis JP, Doucet D, KMcGuffey M . 2002. Advances in modifying and understanding whey protein functionality. Trends in Food Sci \& Technol. 13(5):151159. Doi: 10.1016/S0924-2244(02)00111-5.

Ghassem M, Arihara K, Babji AS, Said M, Ibrahim S. 2015. Purification and identification of ACE inhibitory peptides from Haruan (Channa sriatus) myofibrillar protein hydrolysate using HPLC-ESI-TOF MS/MS. Food Chem. 129: 1770-1777. Doi: 10.1016/j.foodchem.2011.06.051.

Guan H, Diao X, Jiang F, Han J, Kong B. 2018. The enzymatic hydrolysis of soy protein isolate by Corolase PP under high hydrostatic pressure and its effect on bioactivity and characteristics of hydrolysates. Food Chem. 245: 89-96. Doi: 10.1016/j.foodchem.2017.08.081.

Harnedy PA, Parthsarathy V, Mclaughlin CM, O'Keeffe MB, Allsop PJ, Mcsorley EM, O'Harte FPM, FitzGerald R. 2018. Blue whiting (Micromesistius poutassou) muscle hydrolysate with in vitro and in vivo antidiabetic properties. J Funct Food. 40: 137-145. Doi: 10.1016/j.jff.2017.10.045.

Hassan MA, Balange AK, Senapati SR, Martin XKA. 2017. Effect of different washing cycles on the quality of Pangasius hypophthalmus surimi. Fishery Technol. 54: 51-59.

Herawati VE, Nugroho RA, Pinandoyo, Hutabarat J, Prayitno Budi, Karnaradjasa O. 2018. The growth performance and nutrient quality of asian swamp eel Monopterus albus in central java indonesia in a freshwater aquaculture system with different feeds. $J$ Aqua FoodProduct Tech. 1-9. Doi: 10.1080/10498850.2018.1483990.

Himaya SW, Ryu B, Ngo DH, Kim SK. 2012. Peptide isolated from Japanese flounder skin gelatin protects against cellular oxidative damage. J. Agric. Food Chem. 60: 9112-9119. Doi: 10.1021/jf302161m.
Hou Y, Zhou J, Liu W, Yongxia C, Wu L, Yang G. 2014. Preparation and characterization of antioxidant peptides from fermented goat placenta. Korean J Food Sci Annual. 34(5): 769-776.

Ismail I, Huda N, Ariffin F, Ismail N. 2010. Effects of washing on the functional properties of duck meat.Intl JPoultry Sci. 9(6): 556-561. Doi: 10.3923/ijps.2010.556.561.

Jeevitha K, Khora S, Priya KM. 2014. Antioxidant activity of fish protein hydrolysates from Sardinella longiceeps. Int J Drug Dev \& Res. 6(4): 137-145. Doi: 10.5851/kosfa.2014.34.6.769.

Jomova K, Valko M. 2011. Advances in metalinduced oxidative stress and human disease. Toxicology. 283: 65-87. Doi: 10.1016/j.tox.2011.03.001.

Karaulova EP dan Yakush EV. 2017. The comparative study of myofibrillar proteins of skeletal muscles of some deep-sea fish species. J Fish Sci. 11(2): 1-8. Doi: 10.21767/1307-234X.1000112.

Khanh NH dan Ngan HTB. 2010. Current practices of rice field eel Monopterus albus (Zuiew, 1793) culture in Vietnam. Res Institute for Agriculture. 3: 26- 29.

Kiewiet MBG, Dekkers R, Ulfman LH, Groeneveld A, de Vos P, Faas MM. 2018. Immunomodulating protein aggregates in soy and whey hydrolysates and their resistance to digestion in vitro infant gastrointestinal model: new insights in the mechanism of immunomodulatory hydrolysates. Food Funct. 9: 604-613. Doi: 10.1039/c7fo01537b.

Klomklao S, Benjakul S, dan Kishimura H. 2013. Functional properties and antioxidant activity of protein hydrolysates from toothed ponyfish muscle treated viscera extract from hybrid catfish. Food Sci Technol. 48(7): 1483-1489. Doi: 10.1111/ijfs.12116.

Kristinsson HG, Rasco BA. 2000. Fish protein hydrolysates: production, biochemical, and functional properties. Crit Rev Food Sci Nutr. 40(1): 43-81. Doi: $10.1080 / 10408690091189266$.

Laemmli UK. 1970. Cleavage of structural protein during the assembly of the head of bacterophage T4. Nature. 227: 680-685. Doi: 10.1038/227680a0.

Leo EEM, Fernández JJA , Campos MRS. 2016. Biopeptides with antioxidant and antiinflammatory potential in the prevention and treatment of diabesity disease. Biomed \& Pharmacotherapy. 83: 816-826. Doi: 10.1016/j.biopha.2016.07.051.

Lertwittayanon K, Benjakul S, Maqsood S, Encanacion AB. 2013. Effect of different 
salts on dewatering and properties of yellowtail barracuda surimi.Int Aquatic Res. 5: 1-10. Doi: 10.1186/2008-6970-5-10.

Mirzaei M, Mirdamadi S, Ehsani MR, Aminlari M. 2018. Production of antioxidant and ACEinhibitory peptides from Kluyveromyces marxianus protein hydrolysate: purification and molecular docking. J Food and Drug Analysis. 26: 696-705. Doi: 10.1016/j.jfda.2017.07.008.

Moreno PJG, Batista I, Pires C, Bandara NM, Carpio FJE, Guadix A, Guadix EM. 2014. Antioxidant activity of protein hydrolysates obtain from discarded mediterranea fish species. Food Res Intl. 65: 469-476. Doi: 10.1016/j.foodres.2014.03.061.

Mudgil P, Kamal H, Yuen GC, Maqsood S. 2018. Characterization and identification of novel antidiabetic and anti-obesity peptides from camel milk hydrolysates. Food Chem. 259: 46-54.

Doi: 10.1016/j.foodchem.2018.03.082.

Najafian L, Babji. 2015. Isolation, purification and identification of three novel antioxidative peptides from patin (Pangasius sutchi) myofibrillar protein hydrolysates. LWT Food Sci Technol. 60: 452-46. Doi: 10.1016/j.lwt.2014.07.046.

Najafian L, Jafarzade M, Said M, Babji AS. 2013. Biochemical properties and antioxidant activity of myofibrillar protein hydrolysates obtained from patin (Pangasius sutchi). Int J Food Sci Technol. 48: 2014-2022. Doi: 10.1111/ijfs. 12162.

Normah I dan Noorasma M. 2015. Physicochemical properties of mud clam (Polymesoda erosa) hydrolysates obtained using different microbial enzymes. IFRJ. 22(3): 11031111. Doi: 43b2142687e648cb88109098bb5931db.

Ochiai A, Tanaka S, Tanaka T, Taniguchi M. 2016. Rice bran protein as a potent source of antimelanogenetic peptides with tyrosinase inhibitory activity. J Nat Prod. 79: 25452551. Doi: 10.1021/acs.jnatprod.6b00449.

Ovando CA, de Carvalho JC, de Melo Pereira GV, Jacques P, Soccol VT, and Soccol CR. 2018. Functional properties and health benefits of bioactive peptides derived from Spirulina: A review. Food Reviews Int. 34(1): 34-51. Doi: 10.1080/87559129.2016.1210632.

Ovissipour M, Abedian A, Motamedzadegan A, Rasco B, Safari R, Shahiri H. 2009. The effect of enzymatic hydrolysis time and temperature in the properties of protein hydrolysates from persian sturgeon (Acipenser persicus) viscera. 115(1): 238242. Doi: 10.1016/j.foodchem.2008.12.013.
Oyaizu M. 1988. Antioxidative activities of browning products of glucosamine fractionated by organic solvent and thinlayer chromatography. Nippon Shokuhin Kogyo Gakkaishi. 35: 771-775. Doi: 10.3136/nskkk1962.35.11_771.

Pacheco-Aguilar R, Lugo-Sanchez ME, RoblesBurgueno MR. 2000. Postmortem biochemical and functional characteristics of Monterey sardine muscle at $0^{\circ} \mathrm{C}$. JFood Sci. 65: 2586-90. Doi: 10.1111/j.13652621.2000.tb15953.x.

Palupi S, Hamidah S, Yuriani. 2014. Upaya peningkatan pendapatankelompok usaha belut melalui variasi hasilolahan dan kemasan di Godean. Inotek. 18(1): 109119.

Parvathy U, anizam AA, Ninan G, Panda SK, Ravishankar CN. 2018. Characterization of fish protein hydrolysate from red meat of Euthynnus affinis and its application as an antioxidant in iced sardine. J Sci Ind Res. 77: 111-119. Doi: 123456789/43540.

Pisoschi AM, Charegi MC, Danet AF. 2009. Total antioxidant capacity of some commercial fruit juices: electrochemical and spectrophotometrical approaches. Molecules. 14(1): 480-493. Doi: 10.3390/molecules14010480.

Qiao M, Tu M, Wang Z, Mao FJ, Chen H, Qin L, Du M. 2018. Identification and antithrombotic activity of peptides from blue mussel (Mytilus edulis) protein. Int J Mol Sci. 19(1): 138-149. Doi: 10.3390/ijms19010138.

Ranathunga S, Rajapakse N, Kim SK. 2006. Purification andcharacterization of antioxidantative peptide derived from muscle ofconger eel (Conger myriaster). European Food ResTechnol. 222: 310-315. Doi: 10.1007/s00217-005-0079-x.

Ren J, Wang H, Zhao M, Cui C, Hu X. 2010. Enzymatic hydrolysis of grass carp myofibrillar protein and antioxidant properties of hydrolysates. Czech J Food Sci. 28(6): 475-484. Doi: 10.17221/343/2009-CJFS.

Roslan J, Yunos KFM, Abdullah N, Mazlina S, Kamal M. 2014. Characterizations of fish protein hydrolysates from tilapia (Oreochromis niloticus) by products. Agric Sci Pocedia. 2:312-319. Doi: 10.1016/j.aaspro.2014.11.044.

Shahidi F dan Zhong Y. 2015. Measurement antioxidant activity. J Funct Food. 18: 757781. Doi: $\underline{10.1016 / j . j f f .2015 .01 .047 .}$

Shekarabi SPH, Hosseini SE, Soltani M, Kamali A, Valinassab T. 2014. A comparative study on physicochemical and sensorycharacteristics of minced fish and 
surimi from black mouth croaker (Atrobucca nibe).JAgrSciTech. 16: 12891300. Doi: jast.modares.ac.ir/ article-233094.

Slizyte R. Rustad T, dan Storro I. 2005. Enzymatic hydrolysis of cod (Gadus morhua) byproducts: Optimization of yield and properties of lipid and protein fractions. Process Biochem. 40(12): 3680-3692. Doi: 10.1016/j.procbio.2005.04.007.

Song R, Wei RB, Ruan GQ, Luo HY. 2015. Isolation and identification of antioxidant peptides from peptic hydrolysates of halffin anchovy (Setipinna taty). LWT-Food Sci Technol. 60: 221-229. Doi: 10.1016/j.lwt.2014.06.043.

Srikanya K, K Dhanapal, K Sravani, K Madhavi, K Praveen . 2017. A study on optimization of fish protein hydrolysate preparation by enzymatic hydrolysis from tilapia fish waste mince. Int. J Curr Microbiol App Sci. (6): $\quad 3220-3229 . \quad$ Doi: 10.20546/ijcmas.2017.612.375.

Tahergorabi R, Hosseini SV, Jaczynski J. 2011. Food Proteins: Seafood Proteins. Cambridge (GB): Woodhead Publishing.

Thaipong K, Boonprakob U, Crosby K, CisnerosZevallos L, Byrne DH. 2006. Comparison of ABTS, DPPH, FRAP, and ORAC assays for estimating antioxidant activity from guava fruit extracts. J Food Composition Analysis. 19: 669-675. Doi: 10.1016/j.jfca.2006.01.003.

Thiansilakul Y, Benjakul S, Richards MP. 2011. Effect of myoglobin from Eastern little tuna muscle on lipid oxidation of washed Asian seabass mince at different $\mathrm{pH}$ conditions. $J$ Food Sci. 76(2): 242-249. Doi: 10.1111/j.1750-3841.2010.01992.x.

Thorarinsdottir KH, Arason S, Geirsdottir M, Bagason SG, Kristbergsson K. 2002. Changes in myofibrillar proteins during processingof salted cod (gadus morhua) as determined by electrophoresis and differential scanning calorimetry. Food Chem.77(3): 377-385. Doi: 10.1016/S03088146(01)00349-1.

Udenigwe CC dan Aluko RE. 2011. Chemometric analysis of the amino acid requirements of antioxidant food protein hydrolysates. Int $J$ Molecular Sci. 12: 3148-3161. Doi: 10.3390/ijms12053148.

Vijaykrishnaraj M, Roopa BS, dan Prabhasankar P. 2016. Preparation of gluten free bread enriched with green mussel (Perna canaliculus) protein hydrolysates and characterization of peptides responsible for mussel flavour. Food Chem. 211: 715-25. Doi: 10.1016/j.foodchem.2016.05.094.
Vilcacundo R, Miralles B, Carillo W, HernandezLedesma B. 2018. In vitro chemo chemopreventive properties of peptides released from quinoa (Chenopodium quinoa Willd.) protein under simulated gastrointestinal digestion. Food Res Int. 105: 403-411. Doi: 10.1016/j.foodres.2017.11.036.

Wang B, Wang YM, Chi CF, Luo HY, Deng SG, Ma JY. 2013a. Isolation and Characterization of Collagen and Antioxidant Collagen Peptides from Scales of Croceine Croaker (Pseudosciaena crocea). Mar Drugs.11: 4641-4661. Doi: 10.3390/md11114641.

Wang H, Zhang F, Cao J, Zhang Q, and Chen Z. 2013b. Proteolysis characteristics of sarcoplasmic, myofibrillar, and stromal proteins separated from grass carp and antioxidant properties of their hydrolysates. Food Sci. Biotechnol. 22(2): 531-540. Doi: 10.1007/s10068-013-0111-z.

Wattanasiritham L, Theerakulkait C, Wickramasekara S, Maier CS, Stevens JF. 2016.Isolation and identification of antioxidant peptides from enzymatically hydrolyzed rice branprotein. Food chem. 192:156-162.

Doi: 10.1016/j.foodchem.2015.06.057.

Wijayanti HB, Bansal N, dan Deeth HC. 2014. Stability of whey proteins during thermal processing: a review. Comprehensive Rev in Food Sci Food Safety. 13: 1235-1251. Doi: 10.1111/1541-4337.12105.

Wijayanti I, Romadhon, dan Rianingsih L. 2015. Pengaruh Konsentrasi Enzim Papain terhadap Kadar Proksimat dan Nilai Rendemen Hidrolisat Protein Ikan Bandeng (Chanos chanos Forks). PENA Akuatika Volume $12 \quad$ (1): 13-23.Doi: 10.31941/penaakuatika.v12i1.323.

Wu CH, Chen HM, Sdan hiau CY. 2003. Free amino acids and peptides as related to antioxidant properties in protein hydrolysates of mackerel (Scomber austriasticus). Food Res Intl. 36: 949-957. Doi: 10.1016/s09639969(03)00104-2.

Yarnpakdee S, Benjakul S, Nalinanon S, Kristinsson HG. 2012. Lipid oxidation and fishy odour development in protein hydrolysate from Nile tilapia (Oreochromis niloticus) muscle as affected by freshness and antioxidants. Food Chem. 132:1781-1788. Doi: 10.1016/j.foodchem.2011.11.139.

Yathavamoorthi R, Sankar TV, Ravishankar CN. 2010. Effect of ice storage and washing on the protein constituents andtextural properties of surimi from Labeo calbasu (Hamilton, 1822). Indian J. Fish. 57(4): 8591. Doi: 267967851. 
Yazdi MM, Asoodeh A, Chamani JK. 2012. A novel antioxidant and antimicrobial peptide from hen egg white lysozyme hydrolysates. $J$ Func Food. 4(1): 278-286. Doi: 10.1016/j.jff.2011.12.004.

YouL, Zhao M, Cui C, Zhao H, Yang B.2009. Effect of degree of hydrolysis on the antioxidant activity of loach (Misgurnus anguillicaudatus) protein hydrolysates. Innovative Food Sci Emerging Technol. 10(2): 235-240. Doi: 10.1016/j.ifset.2008.08.007.
Zou Tang-Bin, Zou, He Tai-Ping, Li Hua-Bin, Tang Huan-Wen, Xia En-Qin. 2016. The structure-activity relationship of theantioxidant peptides from natural proteins.Molecules. 21(1): 72-86. Doi: 10.3390/molecules21010072. 